\section{Enhancing Egyptian container terminals performance through managing efficiency and competitiveness}

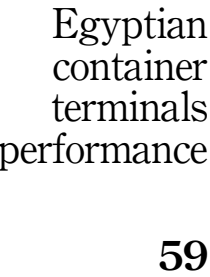

\author{
Sara Elgazzar
}

Arab Academy for Science Technology and Maritime Transport, Alexandria, Egypt, and

Ahmed Ismail
Arab Academy for Science Technology and Maritime Transport, College of International Transport and Logistics, Alexandria, Egypt

Received 4 December 2020

Revised 1 March 2021

Accepted 18 March 2021

\begin{abstract}
Purpose - The importance of container transportation has increased due to the globalization of the world economy. The purpose of this research is at proposing a framework to enhance the container terminals performance through evaluating efficiency and competitiveness.

Design/methodology/approach - The researchers used data envelopment analysis to assess the efficiency and fuzzy analytic hierarchy process to measure competitiveness of container terminals. The proposed framework captures key performance indicators to evaluate the container terminals' performance and identify areas that need improvement. It was applied to the Egyptian container terminals from the period of 2015-2019 as an empirical study.

Findings - Findings highlights the highest utilization of resources of Alexandria port while more attention should be given to the level of service provided. On the other hand, El-Sokhna should focus on more utilization of the available resources. The performance evaluation showed that the rest of Egyptian terminal ports should improve both competitiveness and efficiency at different levels based on their performance ranking.

Research limitations/implications - The developed framework can be used as an evaluation tool to evaluate the performance of container terminals in other countries, and can be utilized as a performance benchmark tool to compare the performance of container terminals of competing ports.

Practical implications - The developed framework can help policymakers to assess efficiency and competitiveness based on both quantitative data and experts' judgement in order to help in formulating government logistics strategy.

Originality/value - The research provides a comprehensive framework to measure and evaluate competitiveness and efficiency of container terminals based on both quantitative data and experts' judgement.
\end{abstract}

Keywords Container terminal, Efficiency, Competitiveness, Data envelopment analysis, Fuzzy analytic hierocracy process, Egypt

Paper type Research paper

\section{Introduction}

Ports are no longer only the nodes where goods and ships are handled but they have become economic competitive areas ( $\mathrm{Lu}$ and Wang, 2017). The map of the world economy is

(C) Sara Elgazzar and Ahmed Ismail. Published in Marine Economics and Management. Published by Emerald Publishing Limited. This article is published under the Creative Commons Attribution (CC BY 4.0) licence. Anyone may reproduce, distribute, translate and create derivative works of this article (for both commercial and non-commercial purposes), subject to full attribution to the original publication and authors. The full terms of this licence may be seen at http://creativecommons.org/licences/by/4.0/ legalcode. 
MAEM

4,1

60

determined by the global transport map, it was found that the place and map of transport trigger economic prosperity (UNCTAD, 2018). Accordingly, ports will not be able to survive and compete unless they complied with the international efficiency and the competitiveness standards (Ismail, 2019).

Production capabilities of container terminals cannot be ignored because container transportation and container industries play an indispensable role in the economy of the world (Cullinane et al., 2006). Container ports play a vital role to the efficiency of the global logistics chain as they link between different modes of transportation (Wang et al., 2005). Therefore, enhancing terminal efficiency is important for the welfare in any country (Esmer, 2008).

Terminal efficiency is a leading indicator of terminal performance; efficient terminals lead to lower transportation costs and facilitate the imports and exports process of a country. Therefore, inefficient terminals lead to high freight and handling cost, which contributes to increasing the prices of import and export. Improving container terminals efficiency remains a high priority issue in any country; therefore, the efficiency plays a significant role in the competitiveness of a container terminal (Almawsheki and Shah, 2015).

The competitive position of a container terminal is determined by what this terminal is offering to host shippers and shipping lines. Container ports should be able to effectively organize their activities by offering nowadays - appropriate range of services. In addition, there is a need of regular evaluation of the effectiveness of their operations in order to plan for the future growth (Munim and Saeed, 2019).

Container terminal performance depends on enhancing efficiency and competitiveness (Yap, 2019). This research aims at proposing a framework to enhance container terminals performance through evaluating efficiency and competitiveness. An empirical study was conducted on the Egyptian container terminals to show the applicability of the proposed framework.

This paper will start in Section 2 by providing a thorough understanding of the concepts of container terminal efficiency and competitiveness and a review of the literature conducted on container terminal efficiency and competitiveness. Section 3 will present methodology used in this research. Section 4 will illustrate the empirical study on the Egyptian container terminals and finally conclusion and agenda for further research will be discussed in Section 5.

\section{Literature review}

Maritime transportation plays an indispensable role in the economic growth and the international trade for all countries. Therefore, maritime transport carried around $80 \%$ of the world trade, thus the performance of ports is a key determinant of countries' competitiveness as a gateway for international trade (UNCTAD, 2018).

Competitiveness and efficiency level in a container terminal are the main indicators of terminal performance (Serebrisky et al., 2016). Worldwide experience has demonstrated that an improvement in the efficiency of the terminal will subsequently increase terminal competitiveness (Chang and Tovar, 2014). Recently, the efficiency of container terminals assists the reduction of maritime cost also; it is one of the key factors of survival in the shipping industry (Ismail and Elgazzar, 2018).

Different techniques have been used to evaluate and benchmark the efficiency of a container terminal from different perspectives depending on the research aims and objectives. Sarriera et al. (2013) and Serebrisky et al. (2016) used stochastic frontier analysis (SFA), Cullinane et al. (2005) and Cabral and Ramos (2018) used Free Disposal Hull (FDH). Kutin et al. (2017) and Ismail (2019) used data envelopment analysis (DEA); while other 
researchers have used integrated approaches combing several techniques such as DEA, SFA and FDH (Serebrisky et al., 2016).

Lu et al. (2015) used a DEA approach by applying Charnes Cooper and Rhodes (CCR), Banker, Charnes and Cooper (BCC) and Scale Efficiency (SE) models to measure the operational efficiency of the 20 leading container ports. Li et al. (2015) evaluated the relative efficiency to determine the current level of efficiency for the major 16 ports in Asia using DEA technique by applying CCR and BCC models. Baran and Górecka (2015) used DEA to assess the Overall Technical Efficiency, Pure Technical Efficiency and Scale Efficiency of container ports based on CCR and BCC models. Nguyen et al. (2015) used both DEA and SFA to underlie the factors of the low levels of efficiency. Jang et al. (2016) used five DEA models to evaluate the efficiency of Asia's container ports. Wiśnicki et al. (2017) mentioned that the automation level of a terminal is not neatly correlated with terminal efficiency by using CCR model on nine European container ports.

The previous analysis declared that DEA technique (particularly its two basic models, CCR model and BCC model) is the most applicable technique has been used to measure port efficiency. It has been used in several earlier studies such as (Chirwa, 2001; Tongzon, 2001; Cullinane et al., 2002; Cullinane et al., 2005; Cullinane et al., 2005a; Cullinane and Wang, 2006; Al-Eraqi et al., 2007; Lin and Tseng, 2007; Al-Eraqi and Khader, 2009; Merk and Dang, 2012; Dyck, 2015). Table A1 summarizes previous research conducted on port efficiency from different perspectives.

In recent years, there has been an exponential growth in the number of publications related to theory and applications of DEA. Cavaignac and Petiot (2017) mentioned that the average annual growth rate of published articles using DEA during the period "2008-2016" in transport field was 36\%. Moreover, the number of articles that used DEA during the period "1989-2016" in the maritime transport sector is $25.7 \%$ "91\% in ports and $9 \%$ in shipping companies" from total articles in other sectors.

Efficiency has always recognized as a vital port competitiveness factor (Kammoun et al., 2018). Competitiveness is the ability to provide products and services as or more effectively and efficiently than the other competitors. Port performance measurement remains a challenge for the port industry as ports strive to compete in an extremely competitive environment. Yeo et al. (2008) identified port cost, port infrastructure, port services quality, hinterland connectivity and port geographical location as main factors in port competitiveness.

Following this study, Yeo et al. (2011) stated that there are 38 factors that affecting the competitiveness of a container terminal; such as quality of the service, transfer and storage, cargo handling cost, efficient inland transport network, terminal productivity and 24 hours/ seven days a week service. Cho and Kim (2015) found that the competitiveness of seaports is correlating with the quality of infrastructure of container.

Analytic hierarchy process (AHP) and technique for order of preference by similarity to ideal solution (TOPSIS) used by Zabihi et al. (2016) to find out the best location in southern seas for container transhipment hub. Hales et al. (2017) used AHP technique to assess the change in port competitiveness.

AHP is the most widely used technique in decision-making due to its promising accuracy, simplicity, ability to handle both qualitative and quantitative criteria or tangible and intangible aspects, also, its ability to measure the consistency of judgement of respondents (Muhisn et al., 2015). The previous analysis declared that AHP as a multicriteria decisionmaking technique can help container terminals' managers to enhance terminals' competitiveness through identifying the relative importance weight of each dimension of competitiveness and define dimensions that are working well and those that need improvements. Table A2 summarizes previous research conducted on port competitiveness from different perspectives. 
MAEM

4,1

62

Efficiency is one of the important factors affecting port competitiveness, which ultimately affects port performance. Merk and Dang (2012) stated that port efficiency is a vital element that affects port competitiveness. From previous studies, it can be noted that limited research tried to provide a comprehensive view of evaluating both terminal efficiency and competitiveness.

In this context, this research will provide a comprehensive framework to measure and evaluate competitiveness and efficiency of container terminals. The framework will utilize DEA to assess the efficiency and Fuzzy Analytic hierarchy process (FAHP) to measure competitiveness of container terminals. The review revealed that DEA as a measure of efficiency deals with quantitative data to measure container terminal performance through evaluating container terminal's facilities as performance input and container terminal's throughput as a measure of output performance. While FAHP as a measure of competitiveness can deal with multicriteria qualitative assessment of various container terminals' performance indicators based on experts' judgement.

\section{Research methodology}

One of the most applicable tools worldwide to evaluate and rank port performance is Logistics Performance Index (LPI). The LPI was created to demonstrate the logistics comparative situation of countries (Çemberci et al., 2015). It is an international tool for benchmarking key barriers and opportunities for improvement as it summarizes the performance through different criteria such as customs; infrastructure; international shipments; logistics quality; tracking and timeliness (Ojala and Çelebi, 2015).

Egypt implemented infrastructure reform, targeting improving logistics performance and competitiveness. However, Egypt's ranking in LPI dropped 18 positions between 2016 and 2018 to rank 67th on the LPI in 2018 as Egypt's logistics performance has worsened in all indexing criteria compared to 2016 (Worldbank.org, 2021). In this context, it is essential to propose a procedure that can help policymakers to assess logistics performance from different dimensions based on both quantitative data and experts' judgement. This can help in identifying the required corrective actions which can ensure the targeted outputs from reform strategy. This research proposes a framework to measure and evaluate competitiveness and efficiency of the Egyptian container terminals, which will be illustrated in this section.

Figure 1.

Research framework

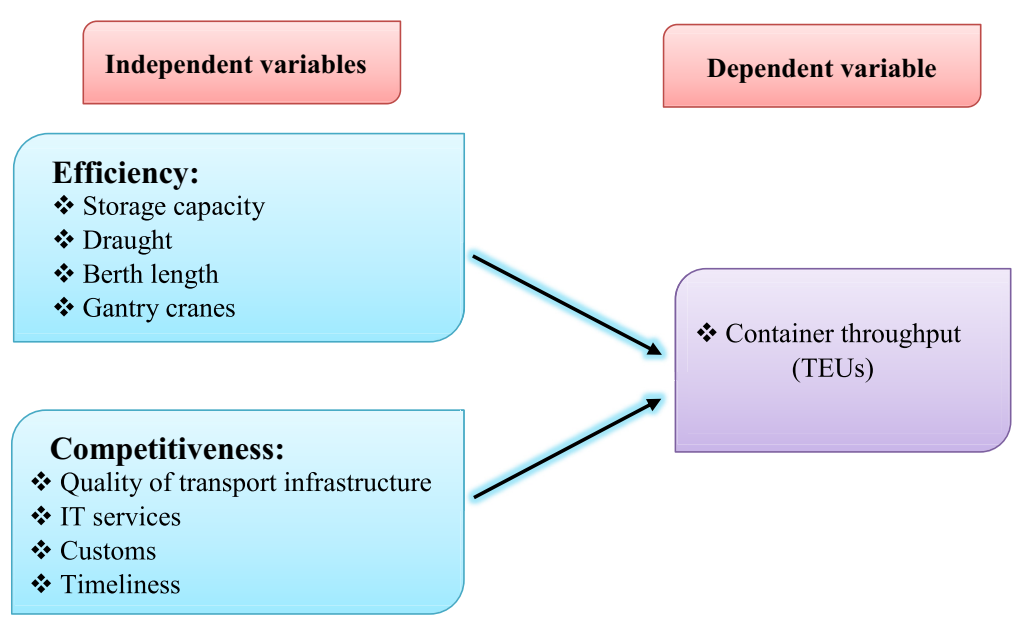


Based on previous studies that have been illustrated in literature review section, the research identified performance measures and proposed the framework - as illustrated in Figure 1 to measure a container terminal performance in terms of efficiency and competitiveness.

The proposed framework defines container throughput (TEUs) as the dependent variable in this research to measure performance output as a result of efficiency and competitiveness (the independent variables). It has been found that most studies widely used container throughput (TEUs) to evaluate port terminal performance as output of the level of efficiency and competitiveness (Hlali, 2018). In this research, TEUs is used as the dependent variable to measure performance output as it is considered a primary basis on which container terminals are compared and benchmarked. Unlike other performance output measures that are too difficult to standardize such as ships call number where two ports could have same ships call numbers while they have different total cargo handled.

In this research for measuring port efficiency, four measures are used based on the most common used measures in literature; "storage capacity" as the total available area for cargo storage, "draught" as the distance between waterline of the ship and the ship's keel, "berth length" as the total available length of berth, and "gantry cranes" which is the equipment that used in container handling process.

Derived from LPI measures, port competitiveness is measured based on quality of transport infrastructure, IT services, customs and timeliness as they present the key drivers of port competitiveness. Quality of transport infrastructure reflects quality of transportrelated infrastructure. IT services measures the port IT capabilities and features. Customs refers to the efficiency of the customs clearance process in terms of speed and simplicity. Timeliness assesses timeliness of shipments in reaching port destination (Ojala and Çelebi, 2015; Roekel, 2017).

The efficiency measures were assessed using DEA technique. The most popular of the nonparametric approaches is data envelopment analysis "DEA". The main attraction of DEA is that it can deal with multiple inputs and outputs. The units in any DEA assessment are generally homogeneous and are independent units performing the same function (Nwanosike, 2014). DEA technique is useful in resolving the measurement of port efficiency because the calculations are nonparametric that can handle more than one output and do not require an explicit priori determination of relationships between output and input (Elsayeh, 2015).

FAHP technique was used as a measure of terminal competitiveness. FAHP has the ability of handling both qualitative and quantitative criteria; it measures the consistency of judgement of respondents, as it is suitable for understanding complex problems by using a hierarchical structure (Elgazzar, 2013).

In the next section, an empirical study on Egyptian container terminals is presented. The applicability of the proposed framework to assess terminal performance in terms of efficiency using DEA technique and competitiveness using FAHP approach will be illustrated, upon which containers' terminals can be ranked and areas of improvement can be identified.

\section{Empirical study}

This section attempts to measure the efficiency and competitiveness of the Egyptian container terminals to find out the present status and the weakness points of these container terminals. The results will highlight areas of improvements that could enhance the efficiency and the competitive position of these container terminals. 
MAEM

4,1

The empirical study focuses on six Egyptian container terminals: Alexandria, El-Dekheila, Port Said, East Port Said, Damietta and El-Sokhna. Adabiya container terminal was excluded due to limitation of data. Secondary data were collected from the Egyptian Maritime Data Bank (EMDB) for the period from 2015 to 2019, while primary data were collected through questionnaires distributed to experts and stakeholders in the field.

\subsection{Efficiency assessment of the Egyptian container terminals}

The researcher used DEA to assess the efficiency of the Egyptian container terminals. Secondary data were collected on: storage capacity, draught, berth length and gantry cranes as measures of performance efficiency input and container throughput as a measure of performance output. Data were collected from the EMDB for the Egyptian container terminals (Alexandria, El-Dekheila, Damietta, East Port Said, Port Said and El-Sokhna) for the duration of five years (from 2015 to 2019) in order to analyse a complete shipping market cycle of the Egyptian container terminals.

Three different DEA models were used to assess the efficiency score of the Egyptian container terminals: CCR model, BCC model and sensitivity analysis (SA) (Cabral and Ramos, 2018). CCR model measures the overall technical efficiency, while BCC model measures the pure technical efficiency (Elsayeh, 2015; Ismail, 2019). SA examines the impacts when an input variable deleted or added (Ramanathan, 2003). This will help to identify the weight of each variable that affects the efficiency score of a container terminal. In this research, the Max DEA v.8 software program, written by Beijing Realworld Software Company Ltd; was used to solve CCR, BCC and SA.

Table 1 shows the Egyptian container terminals' efficiency CCR and BCC scores during the period from 2015 to 2019. The efficiency score of Alexandria terminal was equal to unity only in 2016 and 2019; Port Said port had an efficiency score equal to unity only in 2015; Damietta port had an efficiency score equal to unity only in 2018; East Port Said port had an efficiency score equal to unity only in 2019; under CCR and BCC models. In addition, El-Dekheila port had an efficiency score equal to unity only 2015 and 2019 and El-Sokhna port had an efficiency score equal to unity only 2016 under BCC model.

Based on the analysis, we found that most of the Egyptian container terminals suffer from inefficiency during the period of the study. In addition, it shows that Alexandria container terminal had the highest mean efficiency estimating of 0.838 for both CCR and BCC models. While El-Sokhna container terminal had the lowest mean efficiency estimating of 0.747 for CCR analysis.

SA results are illustrated in Table 2 . The distraction of storage capacity decreased the efficiency score of El-Dekheila, Damietta and El-Sokhna from 0.863 to 0.847 , from 0.928 to 0.776 and from 0.742 to 0.564 , respectively; while increased the efficiency score of Port Said port from 0.952 to unity. The removal of storage capacity has not changed the efficiency score of Alexandria and East Port Said; which is the same equal to unity.

The omission of draught from the input variables combination decreased only the efficiency score of El-Dekheila from 0.863 to 0.8.7. Nevertheless, the omission of the same variable increased the efficiency scores from 0.928 to 0.952 to unity in Damietta and Port Said, respectively, and from 0.742 to 0.798 for El-Sokhna port. The removal of storage draught has not changed the efficiency score of Alexandria and East Port Said port, which is the same equal to unity.

The removal of berth length has not changed the efficiency score of El-Dekheila, which is 0.865 and equal to unity for Alexandria and East Port Said port. However, the removal of berth length has increased the efficiency score of Damietta from 0.928 to unity and El-Sokhna from 0.742 to 0.760 , while decreased the efficiency score of Port Said from 0.952 to 0.659 . 


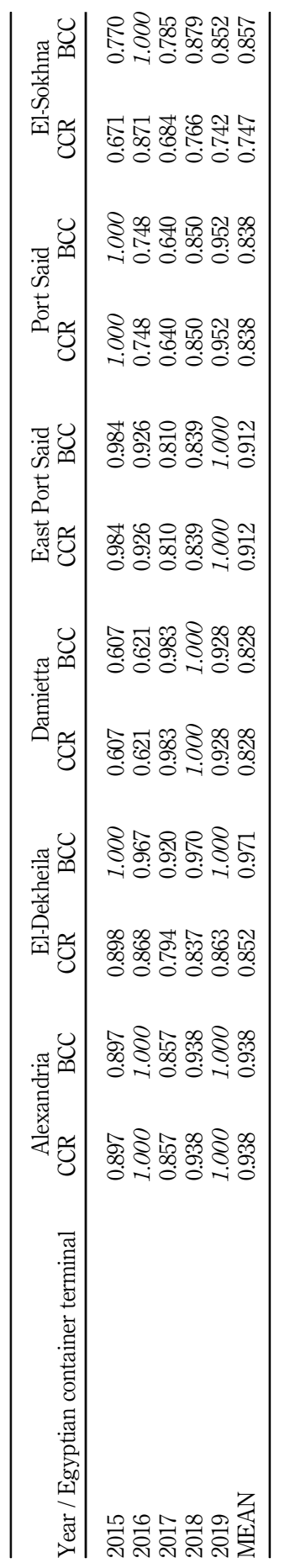

Egyptian container terminals performance

65

Table 1. Egyptian container terminals' efficiency CCR and BCC scores from 2015 to 2019 
MAEM

4,1

\section{6}

The omission of gantry cranes has not changed the efficiency score of East Port Said and still the same equal to unity. However, it decreased the efficiency score of Alexandria and El-Dekheila from equal to unity and 0.863 to 0.828 and 0.750, respectively. While Damietta and Port Said port became efficient and equal to unity instead of efficiency score 0.928 and 0.952 , respectively. Nevertheless, the omission of gantry cranes has increased the efficiency score of El-Sokhna port from 0.742 to 0.798 .

To conclude, the efficiency score of Alexandria port decreased when gantry cranes measure was removed, the efficiency level has not been affected when removing remaining inputs. The efficiency score of El-Dekheila has decreased due to the omission of storage capacity, draught and gantry cranes. While it remained the same when berth length removed from inputs list.

The efficiency score of Damietta has decreased due to removal of storage capacity, but it improved when removing draught, berth length and gantry cranes. The efficiency score of East Port Said has not been changed while removing any of the inputs variables and it remained the same equal to unity. The efficiency score of Port Said has increased due to the removal of storage capacity, draught and gantry cranes, but it decreased when removing berth length. Finally, the efficiency score of El-Sokhna port has increased due to the removal of draught, berth length and gantry cranes, but has decreased due to the removal of storage capacity.

\subsection{Competitiveness assessment of the Egyptian container terminals}

The research assessed container terminals competitiveness using FAHP technique. Four main criteria were used to measure the container terminals competitiveness, namely: quality of transport infrastructure, IT services, customs and timeliness.

A survey was distributed to a group of experts in the field to evaluate the competitiveness level of the Egyptian container terminals. The survey was classified in two main parts. The first part was structured using FAHP approach based on a pairwise comparison scale ranging from 1 to 9 to determine the relative importance weight of each competitiveness criteria. The second part was structured using Likert Scale from excellent to very poor to evaluate the current performance of the Egyptian container terminals in each criteria of competitiveness.

Table 3: illustrates the FAHP questionnaire form to prioritise the competitiveness criteria of a container terminal. While Table 4 illustrates the Likert scale questionnaire form using performance rating scale (excellent, good, very good, poor and very poor) to rank the competitiveness of container terminals, where 1 signifies excellent performance, 0.8 signifies very good performance, 0.6 signifies good performance, 0.4 signifies poor performance and 0.2 signifies very poor performance.

A group of 72 experts in the field from the shipping companies, Egyptian Port Authority and shipping agencies filled the survey. Surveys' responses were analysed

Table 2.

Egyptian container terminals' efficiency sensitivity analysis scores for year 2019

\begin{tabular}{lccccc}
\hline Egyptian container terminals & CCR & Storage capacity & Draught & Berth length & Gantry cranes \\
\hline Alexandria & 1.000 & 1.000 & 1.000 & 1.000 & 0.828 \\
El-Dekheila & 0.863 & 0.847 & 0.807 & 0.865 & 0.750 \\
East Port Said & 1.000 & 1.000 & 1.000 & 1.000 & 1.000 \\
Port Said & 0.952 & 1.000 & 1.000 & 0.659 & 1.000 \\
Damietta & 0.928 & 0.776 & 1.000 & 1.000 & 1.000 \\
El-Sokhna & 0.742 & 0.564 & 0.798 & 0.760 & 0.798 \\
MEAN & & 0.865 & 0.934 & 0.881 & 0.896 \\
& & & &
\end{tabular}




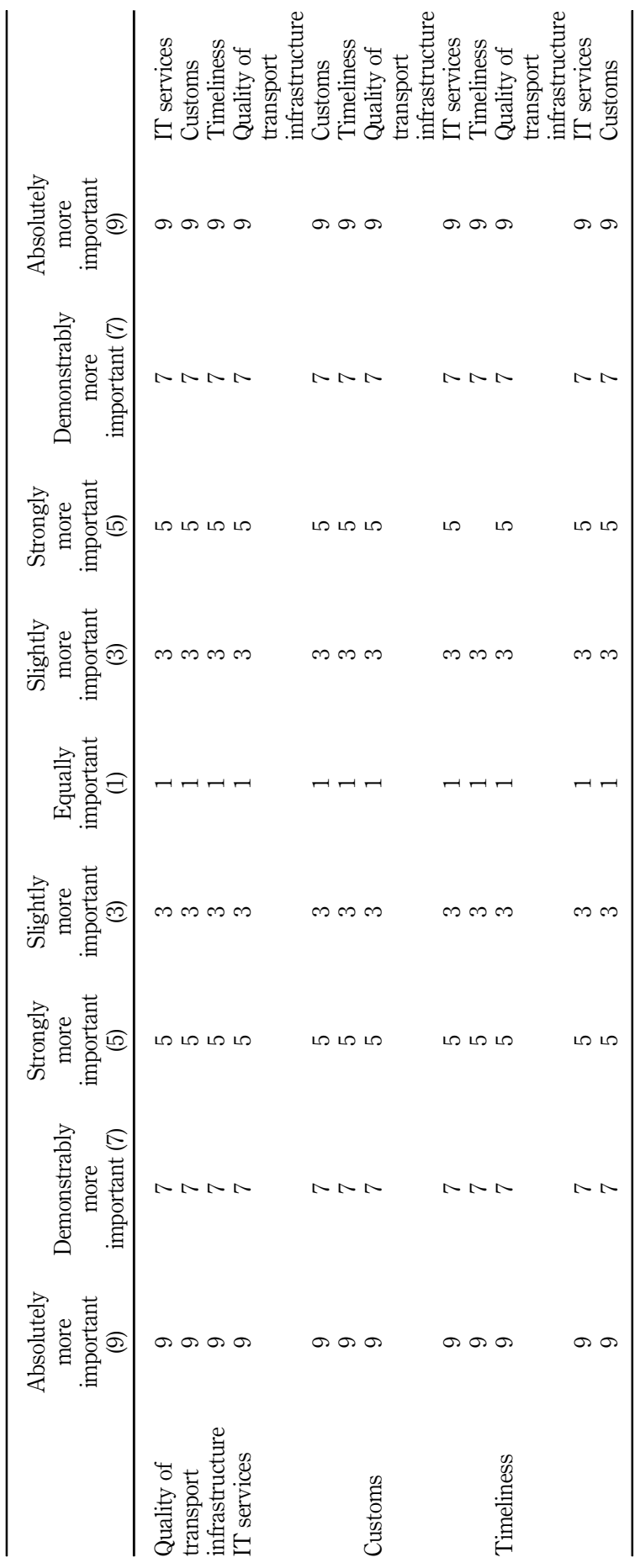

Egyptian container terminals performance

Table 3.

The relative importance weight of the competitiveness criteria 
MAEM

4,1

\section{8}

\begin{tabular}{|c|c|c|c|c|c|c|}
\hline & $\begin{array}{l}\text { Container } \\
\text { terminal }\end{array}$ & Excellent & V. good & Good & Poor & V. poor \\
\hline \multirow{6}{*}{$\begin{array}{l}\text { Quality of transport } \\
\text { infrastructure }\end{array}$} & Alexandria & & & & & \\
\hline & El-Dekheila & & & & & \\
\hline & Port Said & & & & & \\
\hline & East Port Said & & & & & \\
\hline & Damietta & & & & & \\
\hline & El-Sokhna & & & & & \\
\hline \multirow[t]{6}{*}{ IT services } & Alexandria & & & & & \\
\hline & El-Dekheila & & & & & \\
\hline & Port Said & & & & & \\
\hline & East Port Said & & & & & \\
\hline & Damietta & & & & & \\
\hline & El-Sokhna & & & & & \\
\hline \multirow{6}{*}{ Customs } & Alexandria & & & & & \\
\hline & El-Dekheila & & & & & \\
\hline & Port Said & & & & & \\
\hline & East Port Said & & & & & \\
\hline & Damietta & & & & & \\
\hline & El-Sokhna & & & & & \\
\hline \multirow[t]{6}{*}{ Timelines } & Alexandria & & & & & \\
\hline & El-Dekheila & & & & & \\
\hline & Port Said & & & & & \\
\hline & East Port Said & & & & & \\
\hline & Damietta & & & & & \\
\hline & El-Sokhna & & & & & \\
\hline
\end{tabular}

Table 4.

Survey on evaluating the competitiveness of the Egyptian container terminals

using Excel Spreadsheets and Pop Tools to determine the relative importance weight of each criterion.

The maximum accepted Consistency Ratio (CR) to ensure the consistency of the survey findings should be lower than the CR (0.1). In this research, CR was calculated for survey responses $(\mathrm{CR}=0.0159$ ); to verify the consistency of responses, which ensures the consistency of the survey findings as it is lower than the maximum (Saaty and Kearns, 1985; Mu and Rojas, 2017).

Based on survey responses; Table 5 presents the relative importance weights of the measures. The results revealed that: Timeliness has the highest priority with $33 \%$, IT services is placed in the second position with $31 \%$, and Customs has the third priority with $27 \%$, while quality of transport infrastructure comes at the fourth priority with $10 \%$.

After determining the relative weight $(\mathrm{W})$ of each measure, the performance rates $(R)$ for each terminal based on Likert survey responses were determined. The weighted rate (WR) of

Table 5.

Relative importance weights of the container terminals competitiveness measures

\begin{tabular}{llr}
\hline Criteria & & Priority \\
\hline Quality of transport infrastructure & $10 \%$ & 4 \\
IT services & $31 \%$ & 2 \\
Customs & $27 \%$ & 3 \\
Timeliness & $33 \%$ & 1 \\
\hline
\end{tabular}


MAEM each measure for each terminal was calculated by multiplying the weight by the performance 4,1 rate of each measure. Finally, the weighted rates of all measures of competitiveness in each terminal were calculated and aggregated to determine the competitiveness index of each terminal. Based on the aggregated weighted rates, Table 6 shows the competitiveness index of the Egyptian container terminals.

The results revealed that El-Sokhna has the first position with a competitiveness index (0.83), East Port Said comes in the second position, Port Said is in the third position, Damietta is evaluated as the fourth position, El-Dekheila has the fifth position, while Alexandria container terminal takes the lowest position with the lowest competitiveness index (0.69). This index identifies the criteria that need improvement in each Egyptian container terminal.

Table 7 summarizes the performance of each of the six Egyptian container terminals compared to others. As illustrated, although Alexandria container terminal has the highest efficiency level, this is associated with the lowest competitiveness performance compared to other container terminals. This highlights the highest utilization of resources while more attention should be given to the level of service provided in terms of (time, quality, cost and automation). On the other hand, El-Sokhna has the highest competitiveness level while the lowest efficiency level which highlights the importance to focus on more utilization of the available resources through attracting more ships and shipping lines.

The performance evaluation showed that the rest of Egyptian terminal ports should improve both competitiveness (in terms of level of service provided) and efficiency (in terms of resources utilization) at different levels based on their performance ranking.

\section{Conclusion}

This research provided a framework for assessing a container terminal's performance in terms of competitiveness and efficiency. The framework captures key performance indicators to assess the container terminal's performance and identify areas that need improvement. An empirical study on the Egyptian container terminals from 2015 to 2019 was conducted to evaluate their performance and demonstrate the applicability of the proposed framework. This can help policy makers to assess efficiency and competitiveness based on both quantitative data and experts' judgement in order to help in formulating government logistics strategy.

Further research can propose a future agenda to improve the Egyptian container terminals performance through identifying a road map to improve their efficiency and competitiveness based on the assessment provided in this research. The developed framework can be used as an evaluation tool to evaluate the performance of container terminals in other countries, and can be utilized as a performance benchmark tool to compare the performance of container terminals of competing ports.

Table 7.

Performance of the Egyptian container terminals

\begin{tabular}{lcc}
\hline Egyptian container terminals & Efficiency ranking & Competitiveness ranking \\
\hline Alexandria & 1 & 6 \\
El-Dekheila & 3 & 5 \\
Damietta & 5 & 4 \\
Port Said & 2 & 3 \\
East Port Said & 4 & 2 \\
El-Sokhna & 6 & 1
\end{tabular}




\section{References}

Al-Eraqi, A.S. and Khader, A.T. (2009), "DEA Malmquist index measurement in Middle East and East African containers terminals", International Journal of Shipping and Transport Logistics, Vol. 1 No. 3, pp. 249-259.

Al-Eraqi, A.S., Barros, C.P., Mustaffa, A. and Khader, A.T. (2007), "Evaluating the location efficiency of Arabian and African seaports using data envelopment analysis (DEA)", School of Economics and Management, Technical University of Lisbon.

Almawsheki, E.S. and Shah, M.Z. (2015), "Technical efficiency analysis of container terminals in the Middle Eastern region”, The Asian Journal of Shipping and Logistics, Vol. 31 No. 4, pp. 477-486.

Baran, J. and Górecka, A. (2015), "Seaport efficiency and productivity based on data envelopment analysis and Malmquist productivity index", Logistics and Sustainable Transport, Vol. 6 No. 1, pp. 25-33.

Cabral, A.M.R. and Ramos, F. (2018), "Efficiency container ports in Brazil: a DEA and FDH approach", Central European Review of Economics and Management, Vol. 2 No. 1, pp. 43-64.

Cavaignac, L. and Petiot, R.A. (2017), "A quarter century of Data Envelopment Analysis applied to the transport sector: a bibliometric analysis”, Socio-Economic Planning Sciences, Vol. 57, pp. 84-96.

Çemberci, M., Civelek, M.E. and Canbolat, N. (2015), "The moderator effect of global competitiveness index on dimensions of logistics performance index", Procedia - Social and Behavioral Sciences, Vol. 195, pp. 1514-1524.

Chang, V. and Tovar, B. (2014), "Efficiency and productivity changes for peruvian and chilean ports terminals: a parametric distance functions approach", Transport Policy, Vol. 31, pp. 83-94.

Chirwa, E.W. (2001), "Privatization and technical efficiency: evidence from Malawi manufacturing", School of Economic and Social Studies, Working Paper No. WC/03/00.

Cho, H. and Kim, S. (2015), "Examining container port resources and environments to enhance competitiveness: a cross-country study from resource-based and institutional perspectives", The Asian Journal of Shipping and Logistics, Vol. 31 No. 3, pp. 341-362.

Cullinane, K. and Wang, T.-F. (2006), "The efficiency of European container ports: a cross-sectional data envelopment analysis", International Journal of Logistics: Research and Applications, Vol. 9 No. 1, pp. 19-31.

Cullinane, K., Song, D.-W. and Gray, R. (2002), "A stochastic Frontier model of the efficiency of major container terminals in Asia: assessing the influence of administrative and ownership structures", Transportation Research, Vol. 36, Part A, pp. 743-762.

Cullinane, K., Song, D.W. and Wang, T.F. (2005), "The application of mathematical programming Approaches to estimating container port production efficiency", Journal of Productivity Analysis, Vol. 24, pp. 73-92.

Cullinane, K., Wang, T.F., Song, D.W. and Ji, P. (2006), "The technical efficiency of container ports: comparing data envelopment analysis and stochastic Frontier analysis", Transportation Research, Part A 40, pp. 354-374.

Demirel, B., Cullinane, K. and Haralambides, H. (2012), "Container terminal efficiency and private sector participation", The Blackwell Companion to Maritime Economics, pp. 571-598.

Dyck, G.K.V. (2015), "Assessment of port efficiency in West Africa using data envelopment analysis", American Journal of Industrial and Business Management, Vol. 5, pp. 208-218.

Elgazzar, S. (2013), Enhancing the Company's Financial Performance through Managing the Performance of Supply Chain Operations: A Case Study of an Egyptian Manufacturing Company, $\mathrm{PhD}$ Thesis, University of Huddersfield.

Elsayeh, M. (2015), The Impact of Port Technical Efficiency on Mediterranean Container Port Competitiveness, $\mathrm{PhD}$ Thesis, University of Huddersfield.

Esmer, S. (2008), "Performance measurements of container terminal operations", Dokuz Eylul University, Maritime Business and Administration School, Vol. 10 No. 1, pp. 238-255.

Egyptian container terminals performance 
MAEM

4,1

Gökçek, V. and Şenol, Y.E. (2018), "Efficiency analysis of mediterranean container ports", Journal of ETA Maritime Science, Vol. 6 No. 2, pp. 129-140.

Hajizadeh, A., Saeidi, S.N.S., Kaabi, A., Yousefi, H. and Zaredoost, M. (2016), "Relative efficiency analysis of container ports in Middle East using DEA-AP", International Archive of Applied Sciences and Technology, Vol. 7 No. 1, pp. 54-60.

Hales, D.N., Lam, J.S.L. and Chang, Y.T. (2017), “The balanced theory of port competitiveness", Transportation Journal, Vol. 55 No. 2, pp. 168-189.

Hlali, A. (2018), "Efficiency analysis with different models: the case of container ports", Journal of Marine Science: Research and Development, Vol. 8 No. 2.

Hung, S.W., Lu, W.M. and Wang, T.P. (2010), "Benchmarking the operating efficiency of Asia container ports", European Journal of Operational Research, Vol. 203 No. 3, pp. 706-713.

Ismail, A. (2019), Benchmarking the Efficiency of the Egyptian Container Terminals, Unpublished $\mathrm{PhD}$ Thesis, Arab Academy for Science Technology and Maritime Transport.

Ismail, A. and Elgazzar, S. (2018), "Measuring the Egyptian container ports' efficiency: a FUZZY AHP framework", Paper Presented to 23rd Annual Conference of The Chartered Institute of Logistics and Transport, Logistics Research Network (LRN), Plymouth, UK, 5-7 September 2018.

Jang, H.M., Park, H. and Kim, S.Y. (2016), "Efficiency analysis of major container ports in Asia: using DEA and Shannon's entropy", International Journal of Supply Chain Management, Vol. 5 No. 2, pp. 1-6.

Kammoun, R., Abdenadher, C. and Abbes, S. (2018), "Port efficiency and competitiveness: the case of European ports", International Conference of the African Federation of Operational Research Societies, Vol. 124, pp. 313-325.

Kutin, N., Nguyen, T., H. and Vallée, T. (2017), "Relative efficiencies of ASEAN container ports based on data envelopment analysis", Asian Journal of Shipping and Logistics, Vol. 33 No. 2, pp. 67-77.

Li, D., Kwak, K.S., Nam, K.C. and An, Y.M. (2015), "A comparative analysis of terminal efficiency in Northeast Asia container ports", Journal of Navigation and Port Research, Vol. 39 No. 1, pp. 55-60.

Lina, L.C. and Tseng, C.C. (2007), "Operational performance evaluation of major container ports in the Asia- Pacific region”, Maritime Policy and Management, Vol. 34 No. 6, pp. 535-551.

Lu, B. and Wang, S. (2017), Container Port Production and Management, 1st ed., Springer, Beijing.

Lu, B., Park, N.K. and Huo, Y. (2015), "The evaluation of operational efficiency of the world's leading container seaports", Journal of Coastal Research, Vol. 73, pp. 248-254.

Merk, O. and Dang, T.T. (2012), "Efficiency of world ports in container and bulk cargo (oil, coal, ores and grain)", OECD Regional Development Working Papers. 2012/09.

$\mathrm{Mu}$, E. and Rojas, M.P. (2017), “Understanding the Analytic Hierarchy Process”. Practical Decision Making Using Super Decisions, Springer, pp. 7-22.

Muhisn, Z.A.L., Omar, M., Ahmad, M. and Muhisn, S.A. (2015), "Team leader selection by using an analytic hierarchy process (AHP) technique”, Journal of Software, Vol. 10 No. 10, pp. 1216-1227.

Munim, Z.H. and Saeed, N. (2019), "Seaport competitiveness research: the past, present and future", International Journal of Shipping and Transport Logistics, Vol. 11 No. 6, pp. 533-557.

Nguyen, H.O., Nguyen, H.V., Chang, Y.T., Chin, A.T.H. and Tongzon, J. (2015), Measuring port efficiency using bootstrapped DEA: the case of Vietnamese ports, Maritime Policy and Management, The flagship journal of international shipping and port research, Vol. 43 No. 5, pp. 644-659.

Nwanosike, F.O. (2014), Evaluation of Nigerian Ports Post-concession Performance, $\mathrm{PhD}$ Thesis, University of Huddersfield.

Ojala, L. and Çelebi, D. (2015), The World Bank's Logistics Performance Index (LPI) and Drivers of Logistics Performance, International Transport Forum, OECD Papers, Queretaro. 
Ramanathan, R. (2003), An Introduction to Data Envelopment Analysis a Tool for Performance Measurement, SAGE Publications, London.

Roekel, W.V. (2017), Improving International Logistics Performance Measuring, Improving the Logistics Performance Index (LPI) by Assigning Weights to its Six Core Components, Using the Best-Worst Method, Unpublished MSc dissertation, DELFT University of technology.

Saaty, T.L. and Kearns, K. (1985), Analytical Planning, The Organization of Systems Pergamon Press, Oxford, available at: https://www.elsevier.com/books/analytical-planning/saaty/978-0-08032599-6 (accessed 1 February 2009).

Sarriera, J.M., Araya, G., Serebrisky, T., Briceñogarmendía, C. and Schwartz, J. (2013), Benchmarking Container Port Technical Efficiency in Latin America and the Caribbean, The World Bank Latin America and the Caribbean Region Sustainable Development Department, Policy Research Working Paper 6680.

Serebrisky, T., Sarriera, J.M., Suárez-Alemán, A., Araya, G., Briceño-Garmendía, C. and Schwartz, J. (2016), "Exploring the drivers of port efficiency in Latin America and the Caribbean", Transport Policy, Vol. 45, pp. 31-45.

Sohn, J.-R. and Jung, C.-M. (2009), "The size effect of a port on the container handling efficiency level and market share in international transshipment flow", Maritime Policy and Management Journal, Vol. 36 No. 2, pp. 117-129.

Tetteh, E.A., Yang, H.L. and Gomina Mama, F.G. (2016), "Container ports throughput analysis: a comparative evaluation of China and five West African countries", International Journal of Engineering Research in Africa, Vol. 22, pp. 162-173.

Tongzon, J.L. (2001), "Efficiency measurement of selected Australian and other international ports using data envelopment analysis", Transportation Research, Part A 35, pp. 107-122.

Tongzon, J.L. and Heng, W. (2005), "Port privatization, efficiency and competitiveness: some empirical evidence from container ports", Transportation Research, Part A, 39, pp. 405-424.

UNCTAD (2018), Review of Maritime Transport, United Nations, New York.

Wang, T., Cullinane, K. and Song, D.W. (2005), Container Port Production and Economic Efficiency, 1st ed., Palgrave Macmillan.

Wanke, P. and Barros, C.P. (2016), "New evidence on the determinants of efficiency at Brazilian ports: a bootstrapped DEA analysis", International Journal of Shipping and Transport Logistics, Vol. 8 No. 3, pp. 250-272.

Wiśnicki, B., Chybowski, L. and Czarnecki, M. (2017), "Analysis of the efficiency of port container terminals with the use of the data envelopment analysis meth-od of relative productivity evaluation”, Management Systems in Production Engineering, Vol. 1 No. 25, pp. 9-15.

worldbank.org (2021).

Yap, W.Y. (2019), "Container trade and shipping connectivity of Vietnam: implications of comprehensive and progressive agreement for trans-pacific partnership and 21st century maritime silk road", International Journal of Shipping and Transport Logistics, Vol. 11 No. 1, pp. 94-116.

Yeo, G., Roe, M. and Dinwoodie, J. (2008), "Evaluating the competitiveness of container ports in Korea and China", Transportation Research Part A, Vol. 42 No. 6, pp. 910-921.

Yeo, G., Roe, M. and Dinwoodie, J. (2011), "Measuring the competitiveness of container ports: logisticians perspectives", European Journal of Marketing, Vol. 45 No. 3, pp. 455-470.

Yuen, A.C., Zhang, A. and Cheunga, W. (2013), "Foreign participation and competition: a way to improve the container port efficiency in China?", Transportation Research Part A: Policy and Practice, Vol. 49, pp. 220-231.

Zabihi, A., Gharakhani, M. and Afshinfar, A. (2016), "A multi criteria decision-making model for selecting hub port for Iranian marine industry”, Uncertain Supply Chain Management, Vol. 4, pp. 195-206. 


\section{MAEM \\ Appendix}

4,1

74

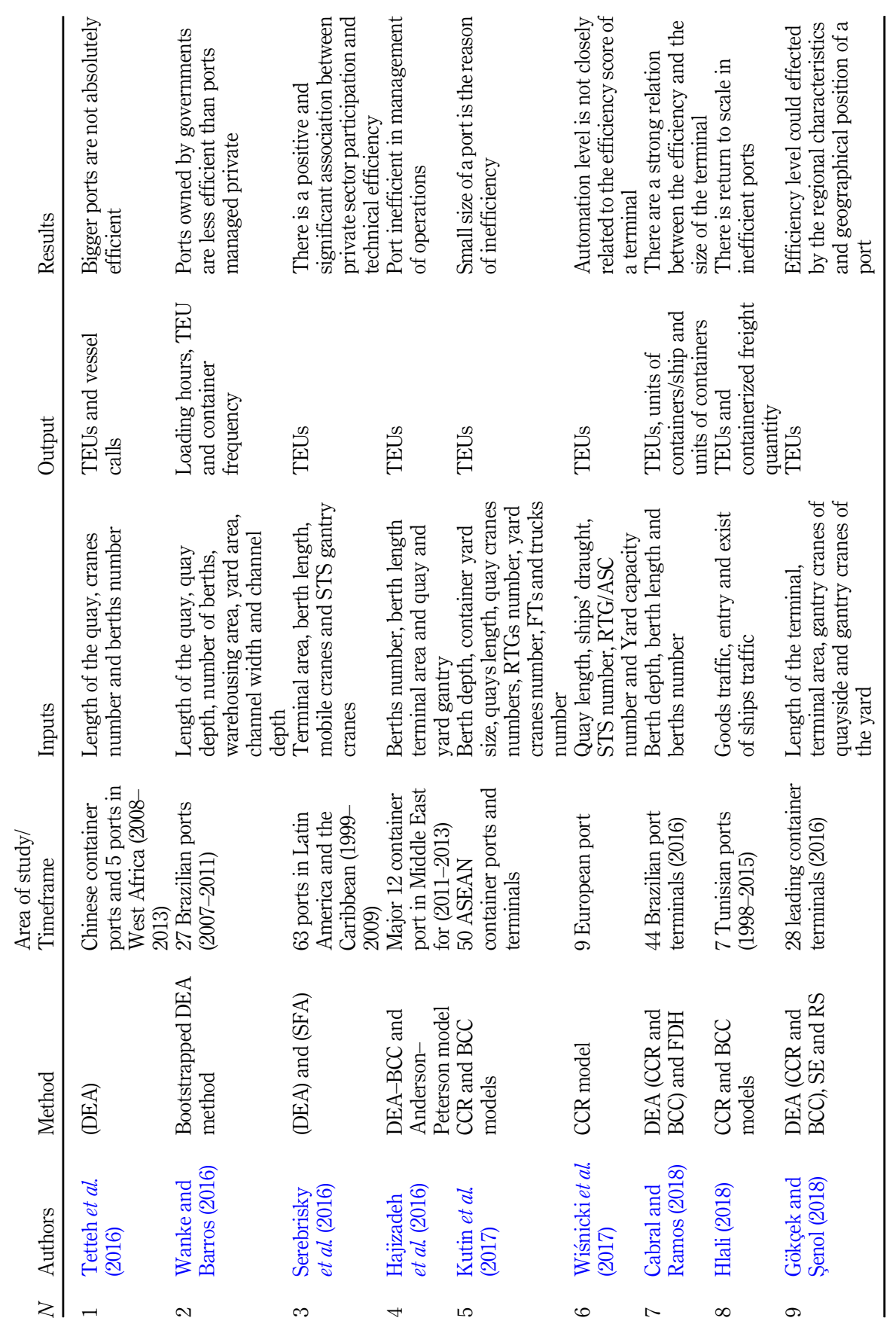

Table A1.

Previous research on port efficiency 


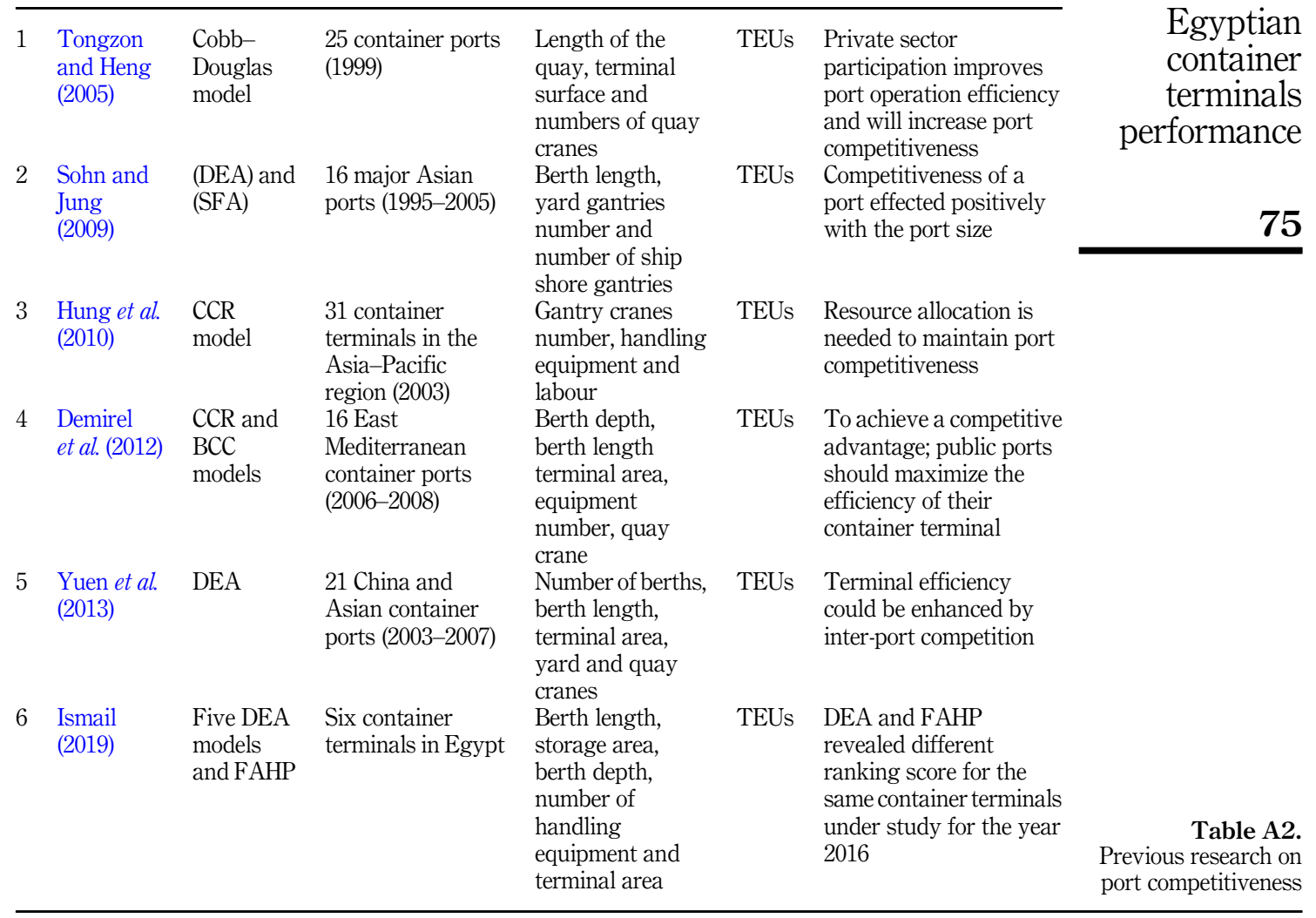

\section{Corresponding author}

Sara Elgazzar can be contacted at: sara.elgazzar02@gmail.com

For instructions on how to order reprints of this article, please visit our website:

www.emeraldgrouppublishing.com/licensing/reprints.htm

Or contact us for further details: permissions@emeraldinsight.com 